\title{
IAMJ
}

INTERNATIONAL

AYURVEDIC

MEDICAL JOURNAL

Research Article

ISSN: 23205091

Impact Factor: 6.719

\section{ASSESSMENT OF ADD-ON-EFFECT OF ANJANA BY HARIDRADI GHRIT IN THE MANAGEMENT OF DRY EYE SYNDROME}

\author{
Alte Priyanka Pandurang ${ }^{1}$, Gopnarayan Atul Ramesh ${ }^{2}$ \\ Assistant Professor, Department of Shalakyatantra, SMBT Ayurved College, Dhamangaon, Nashik, Maharashtra, \\ India \\ Assistant Professor, Department of Kayachikitsa, Dr. Anarsingh Ayurvedic Medical College and Hospital, \\ Fatehgarh, Farrukhabad, Uttar Pradesh, India
}

Corresponding Author: gatul1989ag@gmail.com

\section{https://doi.org/10.46607/iamj04p5012020}

(Published online: November 2020)

Open Access

(C) International Ayurvedic Medical Journal, India 2020

Article Received: 29/09/2020 - Peer Reviewed: 26/10/2020 - Accepted for Publication: 10/11/2020

\section{Check for updates}

\begin{abstract}
In todays life, due to change in environment, food habits and life style it gives rise to different eye diseases. Now a days we see there is exess use of computers and over exposure to visual display terminals, which lead to birth hazard named Dry eye syndrome. In modern science there is not effective treatment for Dry Eye Syndrome. Recently there is increase in number of patients coming in OPD having complaints of foreign body sensation, feeling of dryness, burning sensation, itching, photophobia, tired eye, redness,discomfort etc commonly. In modern science the group of above mentioned symptoms is named as Dry eye syndrome.It is disorder of tear film due to tear deficiency or excessive tear evaporation which leads to damage to outer occlar surface. Incidence of dry eye is $14.3 \%$ in Clinical practice (pub med medical line index). In modern pharmacology the available regimen for the dry eye is using lubricating. But this gives only temporary relief.

While in Ayurveda these symptoms are seen in vitilated vata pitta doshas in eye and will be taken into consideration of title Netrashushkta. In Ayurveda some preparations are there, which can be used as local external application in eye. Ghrit is one of the drug among them which is chakshusya, easily available and more economical to patients. Taking into consideration snehan property of ghrit and vata- pittaghna properties of
\end{abstract}


Haridra and Daruharidra I thought use it in Dry eye syndrome. Hence, I take this topic for research work under the title - To Study The Effect Of 'Haridradi Ghrit Anjana' In The Management Of 'Dry Eye Syndrome'.

Keywords: Kriyakalpa, Anjana, Tear film, Dry eye syndrome, Haridradi Ghrita

\section{INTRODUCTION}

Now a day's peoples are more exposed to pollution due to industrialization. Due to outdoor jobs and prolonged computer work eyes get dry. The factors such as more exposure to wind, sunlight, dust and lack of blinking during computer work hampers the formation of uniform tear film. This results in dryness of cornea which lead to blurring of vision during continuous work. It is a very common condition characterized by disturbances of tear film. This abnormality may result in disruption of ocular surface, causing a variety of symptoms and signs which interfere with the quality of life. Approximately $8 \%$ of the world population is suffering with this eye disorder. The symptoms of dry eye include irritation, foreign body sensations, feeling of dryness, itching, non-specific ocular discomfort. In long standing cases there is conjunctival xerosis, corneal changes in the form of punctuate epithelial erosions and filaments. If left untreated it may lead to many serious complications like corneal ulcer. Hence there is a need to find a safe and effective medication by the form of Ayurvdic formulation. In Ayurvedic classics, we find the concept of Chakshushya and many therapeutic procedures like kriyakalpas explained. Ghrit is one of the Chakshushya. Taking into consideration Snehan property of Ghrit and Vata- Pittaghna properties of Haridra and Daruharidra, Haridradi Ghrit is used in "Anjana" form because it is convenient $\&$ acceptable mode for local instillation of drug.

Aim:

- To study the efficacy of Haridradi Ghrit anjana in the management of Dry Eye Syndrome.

- The study will be aimed to review the literature about Dry Eye Syndrome (Netrashushkta) through the Ayurvedic Samhitas and other classical texts and literature of modern surgical texts.

\section{Objectives:}

- To evaluate the effect of Haridradi Ghrit Anjana in the management of Dry Eye Syndrome.

- To solve todays Dry eye syndrome problem which is now growing day by day due to computers, TV, Air pollution etc. with Ayurvedic line of treatment.

\section{Literature Review:}

\section{Ayurvedic Review}

* According to Acharya Sushruta there are 76 eye diseases.

* In Ayurveda, nomenclature of disease itself denotes self-meaning. every word has some meaning which is introductory and interrelated.

* Netrashushkata is made up of two words netram and Shushkaha, that means the sense organ eye with deficiency of oiliness.

* In Ayurvedic Samhitas Netrashushkata is not described as disease, it is described as a symptom in other diseases. But the two words i.e. Netram and shushkaha are described in Ayurvedic literature.

* Means Netrashushkta is the loss of oiliness and absence of aqueous.

\section{Modern Review}

Dry eye syndrome is the commonest and frequently complaint of patient faced by eye doctors. It is a chronic syndrome due to insufficient lubrication and moisture in the eye. and cause ocular inflammation due to constant irritation of the anterior tissue of eye. It causes damage to the interpalpebral ocular surface and is associated with symptoms of ocular discomfort. Predisposing factors are hot dry and windy climate, excess use of computers, exposure to the dry weather, air conditioning, Cigarette smoke, contact lens wearing, Vitamin A deficiency. There is Tear film instability due to damage of the corneal epithelial cells, mucins which hold to the eye surface. Hence water repellent corneal surface is exposed, and aqueous compo- 
nents are forcefully flushed away. Thus, due to destabilization of tear film increases evaporation and diffusion of tears, Dry eye syndrome develops.

Ayurvedic Review of Anjana:

Kriyakalpa is the main therapeutic process for ophthalmology in Shalakya tantra, as the Panchkarma is the base of Kayachikitsa. In Sharangdhar samhita, seven Netrakriyakalpas are mentioned as

"Sekam Aschotanam Pindi Bidaltarpanam Tatha

Putpaka Anjanam Chaibhi Kalpai Netam Upachret"......... Sharangdhar Samhita 13/1

The Local application of different kinds of medicine in eye is called as Anjana i.e. collyrium. Anjan is the kriyakrama in which medicine is applied in the eye to internal surface of lid margin from Kaneenika sandhi to Apanga sandhi using Shalaka (probe) or by using finger. The references of Anjan is also available in Rigveda. In Ayurvedic samhitas Anjana is the preventive measure and also is a treatment in the speciality of Netraroga.

\section{Procedure of Anjana:}

There can be three steps to do Anjana for better effect and free from side effects:

1. Poorva Karma - preparation of Anjana

2. Pradhana Karma - application of Anjana in the eyes with applicator

3. Pashchata Karma - Netra Prakshalana and Pratayanjana application.

\section{Method of application of Anjana:}

1. An elaborate description of how to apply Anjana is given by Acharya Sushruta.

2. Vartma should be held firmly with left hand so that the patient cannot blink.

3. Hold the Shalaka in right hand and apply the Anjana from Kaneenaka to Apanga where Dalhana commented it should be applied either from Kaneenaka to Apanga or Apanga to Kaneenaka in one shot.

4. After application of Anjana the eyes should remain closed and patient should be asked to mildly rotate the eyeball inside the lids.

Pashchat Karma of Anjana: The eyes look clear and patients see clearly. Then eyes should be washed properly. The Anjana should be removed with the cotton wrapped in the thumb of right hand when it is to be removed from left eye and vice versa.

\section{Material and Methods:}

\section{Materials -}

The trial drug selected for study is Haridradi Ghrita having Constituents as "Haridra, Daruharidra, Saindhava, Ghrita, Jal”,

Method of preparation of Haridradi Ghrit -

"Kalkat Chtaturguneekrutya Ghritam Va Tailamevav Chaturgune Drave Sadhyam Tasya Matra Palonmita" Haridradi Ghrit is prepared according to Snehakalpanavidhi mentioned by Sharangdhara samhita.1 part of each of Haridra, Daruharidra, Saindhav Kalka, 4 parts of Goghrit and 16 parts of water are boiled together till water gets evaporated and only Ghrit remains behind. This suspension is then filled properly which is ready for use.

\section{Methodology}

\section{Selection of Patients:}

Total Sample size of my study is 60, selected from those attending the Netrarog O.P.D. It was done after taking proper written informed consent of the patient and explaining to him the whole work to be done, provided the information of the subject to be confidential.

\section{Inclusion Criteria:}

$>$ Patients willing for trial.

$>$ Patients suffering from Dry eye syndrome.

$>$ Patients of age group between 10yrs to 60 years was chosen

\section{Exclusion Criteria:}

$>$ Patients not willing for clinical trials.

$>$ Age below 10yrs and above 60 yrs.

$>$ Immunocompromised patients and patients with any systemic disorders, Diabetes Mellitus \& hypertension.

\section{Clinical Study}

A single blind, prospective study was conducted for 60 patients. Anjana with Haridradi Ghrit is applied two times in a day morning and evening for 30 days. 


\section{Criteria of Assessment-}

Improvement in the patient was assessed on the basis of relief in the signs \& symptoms of Dry eye syndrome.

1) Dryness of eye (Schirmer I test)

$$
\begin{array}{|l}
\hline 0 \text { (No) } \\
+ \text { (Mild) } \\
++ \text { (Moderate) } \\
\text { +++ (severe) }
\end{array}
$$

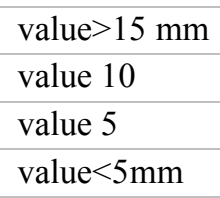

value $<5 \mathrm{~mm}$

2) Foreign body sensation -visual analogue scale

\begin{tabular}{|l|l|}
\hline 0 & No pain \\
\hline $1-3$ & Mild pain (Occasionally present) \\
\hline $4-7$ & Moderate pain (intermittently present) \\
\hline $8-10$ & Severe pain (frequently present) \\
\hline
\end{tabular}

\section{3) Itching -}

\begin{tabular}{|l|l|}
\hline 0 & Absent \\
\hline+ & Mild - patient does not complain itching but have some feeling of itching \\
\hline++ & Moderate- patient complains of itching for some duration of day \\
\hline+++ & Severe - same amount of itching that has before treatment \\
\hline
\end{tabular}

\section{4) Redness-}

\begin{tabular}{|l|l|}
\hline 0 & No congestion \\
\hline 1 & Occasional congestion with clear pattern blood vessel. \\
\hline 2 & Intermittent congestion with clear pattern blood vessel \\
\hline 3 & Congestion with disturbed pattern blood vessel. \\
\hline
\end{tabular}

\section{Observations}

1 Statistical analysis of relief in Dryness of eyes before and after treatment

\begin{tabular}{|l|l|l|l|l|l|l|}
\hline dryness of eyes & \multicolumn{2}{l}{ Median } & Wilcoxon Signed Rank W & P-Value & \% Effect & Result \\
\hline & BT & AT & & & & \\
\hline & 2 & 1 & $-7.508^{\mathrm{a}}$ & 0.000 & 51.7 & Significant \\
\hline
\end{tabular}

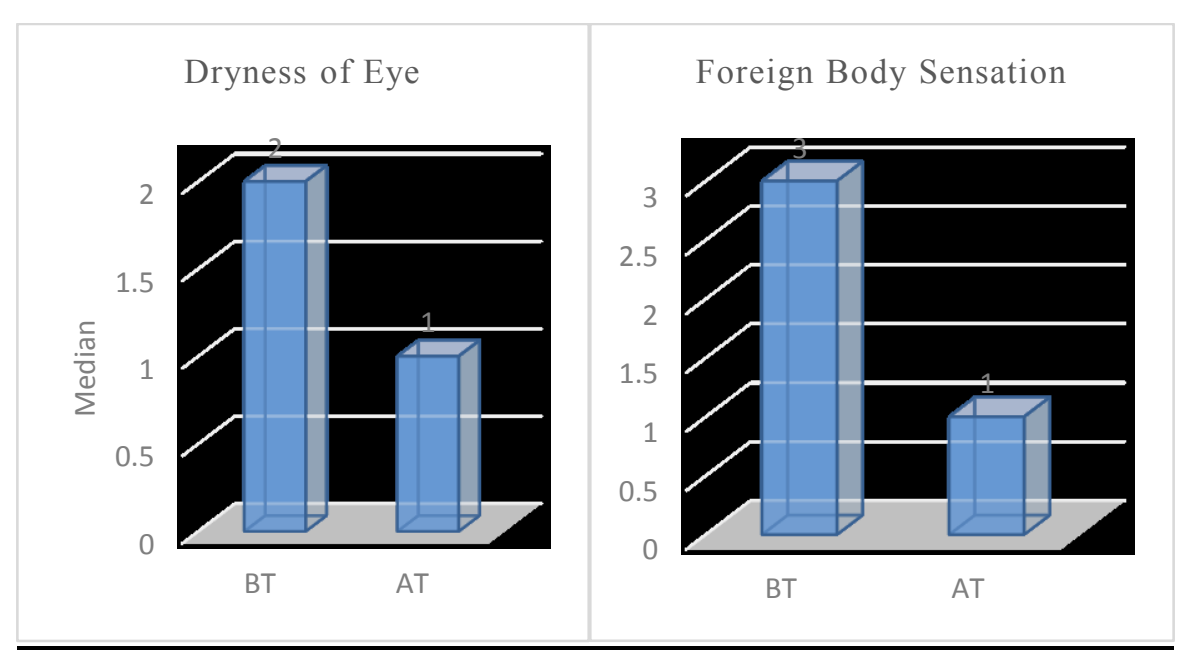


2. Statistical analysis of relief in Foreign body sensation before and after treatment

\begin{tabular}{|l|l|l|l|l|l|l|}
\hline $\begin{array}{l}\text { foreign } \\
\text { sensation }\end{array}$ & body & Median & Wilcoxon Signed Rank & P-Value & $\%$ Effect & Result \\
\cline { 2 - 6 } & BT & AT & W & & & \\
\hline & 3 & 1 & $-6.936^{\mathrm{a}}$ & 0.000 & 80.8 & Significant \\
\hline
\end{tabular}

3. Statistical analysis of relief in Itching before and after treatment:

\begin{tabular}{|l|l|l|l|l|l|l|}
\hline Itching & Median & Wilcoxon Signed Rank & P-Value & \% Effect & Result \\
\cline { 2 - 6 } & BT & AT & W & & & \\
\hline & 2 & 1 & $-6.861^{\mathrm{a}}$ & 0.000 & 46.3 & Significant \\
\hline
\end{tabular}

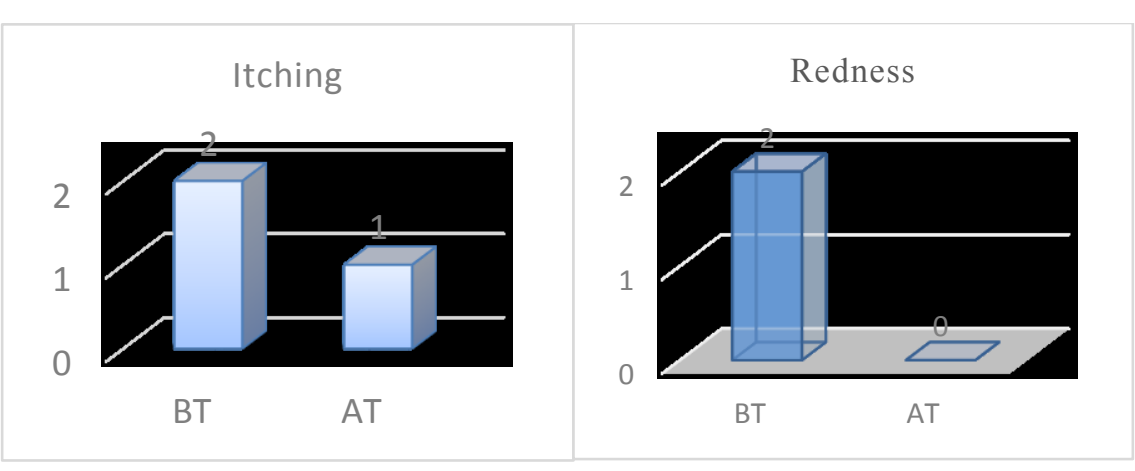

4. Statistical analysis of relief in Redness before and after treatment:

\begin{tabular}{|l|l|l|l|l|l|l|}
\hline \multirow{2}{*}{ Redness } & Median & $\begin{array}{l}\text { Wilcoxon } \\
\text { Rank W }\end{array}$ & Signed & P-Value & $\%$ Effect & Result \\
\cline { 2 - 7 } & BT & AT & $-6.685^{\mathrm{a}}$ & 0.000 & 77.2 & Significant \\
\hline
\end{tabular}

\section{Relief in Percentage -}

The average overall relief of the mentioned symptoms is summarized in a single table given below. It is described with the help of percentage parameter.

\begin{tabular}{|l|l|l|}
\hline Sr. No. & Symptom & Relief in \% \\
\hline 1 & Dryness of eye & $51.7 \%$ \\
\hline 2 & f.b sensation & $80.8 \%$ \\
\hline 3 & Itching & $46.3 \%$ \\
\hline 4 & Redness & $77.2 \%$ \\
\hline
\end{tabular}

Statistically there is highly significant relief $(\mathrm{p}<0.01)$ observed in Foreign body sensation of eyes after treatment.

\section{DISCUSSION}

There are various formulations which are prescribed for the treatment of Dry eye syndrome in modern medicine. But, Anjana with Haridradi Ghrit is more effective in treatment of dry eye. Haridradi Ghrit contains Haridra, Daruharidra, Saindhav, Goghrit. Haridra and, Daruharidradra has anti-inflammatory, antiallergic properties. Its chemical composition Curcumin is useful in reducing inflammation, burning sensation and redness in the eyes due to its antiinflammatory property. While Saindhav Lavan is Pachak, Deepak, Laghu, Snigdha, Heema Gunatmak. It also has Rochak, Vrishya and Tridoshaghna properties. Due to its all above properties it is most useful in eye diseases. Having Lavana with Madhur Rasa, Madhur Vipaka, Sheetavirya does not produces burning sensation and it is tridoshghna so it is best among the Chakshushya. Ghrita is best among four snehana dravya having Yogavahi \& Sanskaranuvartan Guna i.e. it takes the Gunas (Qualities) of other Dravyas not without changing its own property. Yogavahi guna of ghrita which is explained by Charakacharya goes upto the depth of Netragatadhatu with its own properties. Due to its Sneha guna it is Vataghna in nature. \& pittaghna property is due to its madhura Rasa. Ghrit contains K2 and lionelic acid. It is also having antiinflammatory and anti-cancer property. Ghrit is also rich in vitamin A. Supplementation of Vitamin A re- 
duces and treats dryness which occurs due to its deficiency. For immediate Netrasnehan Ghrit should combine with Saindhava. This occurs due to Sukshma, Abhishyandi, Snigdha, Vyavayi guna of Saindhava \& Yogvahi guna of Ghrit. In Netra-Anjana all these properties nourish the conjunctival as well as corneal layers and avoid dryness and inflammation of tissue of conjunctiva and cornea. So, it gives smoothening to layers of conjunctiva and cornea. Its Chakshushya Guna improves the health status of eyes.

\section{CONCLUSION}

The clinical study revealed that use of Netra Anjana with Haridradi Ghrit in patient of Dry eye syndrome helps to cure dryness. It also improved the health status of eyes. By Haridradi Ghrit Anjana it is proved that Dry eye syndrome can be managed with conservative line of treatment in the initial stages. Overall relief was also better in Dry eye syndrome. All patients got marked improvement in symptoms of Dry Eye Syndrome. No adverse effect was found after application of Anjana with Haridradi Ghrit. At the end of the treatment it is observed that in future this work may be valuable clue for further study. Hence, we can conclude that use Haridradi Ghrit Anjana as topical medication can be effective in the management of dry eye syndrome.

\section{REFERENCES}

1. Dr. Haridas Kasture, 2007, (10th edition) Alahabad, Shri. 'Ayurvediya Panchkarma Vigyan' Baidyanath Ayurved Bhavan, 2007.

2. Vaidya Yadavji Trikamji Acharya, 1997, Sushruta Samhita with the Nibandhsangraha Commentary, Varanasi, Chaukhamba Oriental Publications.

3. Pandit Hari Sadashiv Shastri, 2010, Ashtanghridaya, with Sarvagasundari and Ayurved Rasayana commentary, Varanasi, Chaukhamba Surabharati Prakashana.

4. Acharya Thakkar V., Ashatangsangraha, with Indu commentary, New Delhi, Kendriya Anusandhana Parishada.

5. Shri Yadunandanopadhyaya, 2008, Madhavnidana, with Madhukosha commentary, Varanasi, Chaukhamba Oriental Publications.
6. Vaidya Shri Laxmipati Shastri, 2009, Yogaratnakara, with Vidyotini commentary, Varanasi, Chaukhamba Prakashana.

7. Prof. Siddhinandan Mishra, 2005, Bhaishsjyaratnavali, with Siddhiprada commentary, Varanasi, Chaukhamba Surabharati Prakashana.

8. Dr. Brahmanand Tripathi, 2007, Sharangadhara Samhita, with Deepika commentary, Varanasi, Cahukhamba Surbharati Prakashana.

9. Dr. Chunekar K. C., 2006, Bhavaprakasha Nighantu, Varanasi, Chaukhamba Bharati Academy.

10. Dr. Haridas Kasture, 2007, (10 ${ }^{\text {th }}$ edition) 'Ayurvediya Panchkarma Vigyan' Allahabad, Shri. Baidyanath Ayurved Bhavan, 2007.

11. BK Mahajan - Methods of Biostatistics, New Delhi, Jaypee Publishers.

12. S. S. Badrinath, Prema Padmanabhan, 2012, $2^{\text {nd }}$ edition, 'Clinical Practice Patterns in Ophthalmology' Chennai, Shankara Netralaya.

13. A. K.Khurana, Indu Khurana, 2010, reprint $2^{\text {nd }}$ edition, 'Anatomy and Physiology of Eye', New Delhi, CBS Publishers

14. Ramanjit Sihota, Radhika Tandon, 2011, reprint $21^{\text {st }}$ edition, 'Parson's Diseases of the Eye', New Delhi, Reed Elsevier Pvt. Ltd.

15. Ocular Drug Permeability, International Journal of Pharmacological Research and Allied Sources. Vol 1 issue 3 (2012).

16. International Journal of Pharmacy \& Pharmaceutical Sciences. Vol. 2, suppl-2, 2010, ISSN-0975-1491

\section{Source of Support: Nil \\ Conflict of Interest: None Declared}

How to cite this URL: Alte Priyanka Pandurang \& Gopnarayan Atul Ramesh: Assessment Of Add-On-Effect Of Anjana By Haridradi Ghrit In The Management Of Dry Eye Syndrome. International Ayurvedic Medical Journal \{online\} 2020 \{cited November, 2020\} Available from: http://www.iamj.in/posts/images/upload/2570 2575.pdf 